Revista Iberoamericana. Vol. LXIV, Núms. 184-185, Julio-Diciembre 1998; 629-630

\title{
PAZ CON NOSOTROS, PAZ ENTRE NOSOTROS
}

\author{
POR \\ BELla JozeF \\ Profesor Emeritus \\ Universidad Federal de Rio de Janeiro, Brasil
}

In memoriam

Así empezaba yo el discurso de bienvenida a Octavio Paz, cuando vino a Río de Janeiro, invitado por el Ministerio de la Educación y la Fundación Roberto Marinho, el dia 16 de mayo de 1985 y me atreví a saludarlo con un poema sacado de sus mismos versos. Me sonrió, entre admirado y agradecido. No era la primera vez que nos encontrábamos. Lo había visto en México y París, lo había leído con fervor y hasta entrevistado. En el año 1991, le dediqué el número 5 de la revista América Hispánica, como homenaje a su merecido Nobel de Literatura, con ensayos, entre otros, de Dario Puccini, Luciana Stegagno Picchio y Raul Bañuelos.

Octavio Paz hizo coexistir, en notable armonía, el canto poético y la reflexión ensayística. Sus libros abiertos y claros, de páginas indispensables, nos contaminaron con su inteligencia, su razonamiento tan personal, haciéndonos ver que el ensayo puede ser obra de creación, a través de los signos en rotación, nunca cristalizados ni enturbiados por algún pensamiento menor.

Uno de los fundadores de la poesía del siglo $\mathrm{XX}$, en sus poemas busca el sentido original de las cosas, para devolver la magia primitiva a las palabras, nos dice de la "consagración del instante" y el regreso al "tiempo original", al encuentro de sí mismo. Como abridor de caminos, consultó el surrealismo, la filosofía hindú o judaicogriegocristiana, el esoterismo y el erotismo.

Hay en el pensamiento crítico de Paz, de amplitud teórica, una idea-clave: la ruptura de la soledad para alcanzar la comunión. El yo es la soledad. El esfuerzo para conseguir la comunicación puede ser el poema, el gesto, la música, la pintura $\mathrm{y}$, como indica LeviStrauss, el lenguaje. En nuestro siglo,uno de los más críticos de la historia de la humanidad, cuando vemos un universo que se desagrega, el yo también se desagrega y la totalidad dejó de ser pensable excepto como ausencia o colección de fragmentos heterogéneos. La dispersión de la imagen del mundo en fragmentos inconexos se resuelve en pérdida de "otredad". El mundo como imagen desaparece y en su sitio se levantó la realidad de la técnica. El objeto de la búsqueda del poeta es el otro, un salirse del própio yo, para mirarse desde el otro. La poesía será, para Paz, la "revelación de la esencial heterogeneidad del ser, erotismo, otredad". Pero el hombre occidental no ve el cuerpo como disyunción: de ahí el 
dualismo de nuestras civilizaciones, su maniqueísmo. El hombre oriental, según lo que Paz vio durante sus años de permanencia en India, alcanzó vislumbrar esos opuestos bajo la forma de conjunciones. Solo en el tiempo cíclico Paz ve la unidad de los opuestos y la esperanza de reconciliación. El tiempo es un presente donde el pasado y el futuro se reconcilian.

A partir de El laberinto de la soledad, obra compleja y densa, Paz concibe a la naturaleza humana como dividida. El otro es la mitad perdida y solamente gracias a las vivencias privilegiadas del amor, la imagen poética y lo sagrado, el hombre conseguirá ser quien es, podrá alcanzar en sí mismo el otro Margen. En obras posteriores, como PostScriptum, busca la naturaleza humana en otra unidad de opuestos: la unidad más general de los signos cuerpo y no cuerpo.

Paz nos ofrece la esperanza de una palabra poética que será la propia historia y vida. También en este mundo en dispersión, cabrá al lenguaje dar presencia a los demás. Sólo por el arte habrá la posibilidad de escapar a la masificación. Somos contemporáneos de todos los hombres por la palabra, "libertad que se inventa y me inventa cada día".

Con el fallecimiento de Octavio Paz desaparece una de las figuras principales de la cultura hispanoamericana. Negador de determinismos, permanente analista de la actualidad, su pensamiento, ejemplo de lucidez y dignidad, expresado en un español clásico y sobrio, quiso impedir todo reduccionismo de la realidad, defendiendo la libertad de la cultura, haciéndonos ver, siempre, las cosas esenciales. En su afán por demostrar que la verdad no es unidimensional, participó de las aventuras más significativas de este siglo, afirmando que la función fundamental del escritor es la de defender la libertad y la democracia, pero su único partido debe ser el de la verdad. En la crisis de la modernidad, consideraba como misión del intelectual el investigar, crear y transmitir conocimientos y valores y, en seguida, criticar la sociedad como sus hábitos e instituciones. Enemigo de la intolerancia, no existía para el escritor mexicano una certidumbre de las ideologías con pretensiones enciclopédicas o verdades inmutables. En Tiempo nublado critica el autoritarismo de algunos regímenes contemporáneos: "Sin tolerancia , sin libertad de crítica, no hay modernidad".

Fue "uno de los maestros fundamentales de las letras castellanas y universales" dijo de él, con mucha razón, Gabriel García Márquez.

Por la lucidez con que nos condujo al conocimiento de algunos mundos poéticos que analizó con sabiduría (y al suyo propio), por devolver a la crítica su función creadora, en el sentido de inventar una literatura, a partir de las obras - y una cultura- los ensayos de Paz merecen nuestra constante reflexión.

Sin renunciar al futuro ni olvidar el pasado, su obra vivirá en nosotros, en alta claridad, en un presente perpetuo, donde habita la palabra verdadera. 